\title{
BMJ Open Epidemiology of cancers in Lahore, Pakistan, among children, adolescents and adults, 2010-2012: a cross-sectional study part 2
}

Farhana Badar, Shahid Mahmood

To cite: Badar F, Mahmood S. Epidemiology of cancers in Lahore, Pakistan, among children, adolescents and adults, 2010-2012: a cross-sectional study part 2. BMJ Open 2017;7:e016559. doi:10.1136/ bmjopen-2017-016559

- Prepublication history and additional material for this paper are available online. To view these files, please visit the journal online (http://dx.doi. org/10.1136/bmjopen-2017016559).

Received 22 February 2017 Revised 30 September 2017 Accepted 4 October 2017

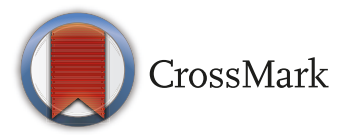

Cancer Registry and Clinical Data Management, Shaukat Khanum Memorial Cancer Hospital and Research Centre, Lahore, Punjab, Pakistan

Correspondence to Dr Farhana Badar; farhana@skm.org.pk

\section{ABSTRACT}

Objectives To estimate the cancer incidence by age group for the Lahore district population within the Punjab Cancer Registry (PCR), Pakistan. The average annual population of Lahore was 9.8 million in 2010-2012. This is a sequel to a study published earlier.

Design A cross-sectional study.

Setting The registry has 19 centres in Lahore reporting their data to the coordinating office located within the Shaukat Khanum Memorial Cancer Hospital and Research Center (SKMCH\&RC), Lahore, Pakistan.

Participants Data existing in the PCR database, based on a confirmed diagnosis of cancer from 1 January 2010 to 31 December 2012, among the Lahore residents, were reviewed.

Outcome measures Cancer counts and the agestandardised incidence rates (ASIR) per 100000 population were computed by gender, cancer site/type and age group (0-14, 15-19 and $\geq 20$ years).

Results Between 2010 and 2012, of the 15840 new cancers diagnosed, $57 \%$ were in females. The ASIRs in age groups $0-14,15-19$ and $\geq 20$ years, among females, were: 6.1, 8.4 and 170.7, respectively, and among males, 9.3, 12.2 and 104.5, respectively. The common diagnoses in children, adolescents and adults were: (1) among females: leukaemia: 2.2; bone tumour: 1.4 and breast cancer: 79.2, respectively, and (2) among males: leukaemia: 3.6 ; bone tumour: 2.4 and prostate cancer: 10.7 , respectively.

Conclusions The ASIR was higher in adult women than in men, but it was lower in girls and young women than their corresponding male counterparts. Leukaemia was the most common diagnosis in children and bone tumour in adolescents, regardless of gender. Among women, breast cancer and, in men, prostate cancer, were the leading cancer types, in adults. These estimates could be used for the expansion of health coverage in the region including setting-up low cost, diagnostic tests for early detection of cancers.

\section{INTRODUCTION}

Pakistan is a less-developed country, categorised as a lower middle-income country, by the World Bank, and ${ }^{1}$ it is also a densely populated country with its population estimated at 195.4 million in $2016 .^{2}$ Being a

\section{Strengths and limitations of this study}

This is the first time that the age-standardised incidence rates have been presented for the Lahore district population separately for children, young adults and adults.

- A comparison has been made with the incidence rates reported by other registries around the world, where available.

- Due to sparse data available from districts contiguous to Lahore district within Punjab, comparisons with the surrounding districts could not be made.

heavily populated country with limited resources, certain systems, well established in the more developed countries of the world, are still in the evolving phase in our country. This includes the non-communicable disease surveillance, including cancer registration, which has long been neglected in the region. Setting up and running a registry is a challenging task but is undoubtedly needed in developing countries of the world including Pakistan. In 2005, a population-based registry called the Punjab Cancer Registry (PCR) was set up through the joint efforts of professionals representing different healthcare facilities within the district of Lahore, in the province of Punjab, Pakistan. ${ }^{3}$ In 2016, we published a paper on the PCR with details related to the cancers registered, over a 3-year period from 2010 to 2012, within the Lahore district, a populous district of the 36 districts of the province of Punjab, Pakistan. ${ }^{4}$ The aforementioned paper was the first paper to report the cancer incidence within the population of the district of Lahore. The current paper is a sequel to the paper published earlier, giving the cancer statistics for the district of Lahore by age category. The goal of the study is to provide the age-adjusted incidence rates for children, young adults/ adolescents and adults. 


\section{METHODS}

The PCR has 19 centres in Lahore that report their data to the collaborating office located within a charitable organisation, the Shaukat Khanum Memorial Cancer Hospital and Research Center, Lahore, Pakistan. For the purpose of data collection, active and passive methods were used. Active method involved a review by the registry staff of the outpatient and inpatient medical records of the patients and abstraction of data onto special forms. Records included pathology reports and clinical notes from outpatient clinics and indoor patient departments representing medical and radiation oncology, radiology and surgery. However, passive notifications were carried out by healthcare workers/front desk staff other than the registry staff and reported to the registry staff.

Evaluating the data initially retrieved from the PCR database to conduct a retrospective review of the records for our first population-based study on newly diagnosed malignancies in Lahore between 2010 and 2012, we conducted another study to compute the incidence rates for three age categories: 0-14 (children), 15-19 (adolescents) and $\geq 20$ years (adults), according to gender and cancer site/type. All cancers were categorised using the International Classification of Diseases, Clinical Modification, 10th revision. ${ }^{5}$ Further groups were created using the International Classification of Childhood Cancer definitions, based on site and morphology coded according to the third edition of the International Classification of Diseases for Oncology. ${ }^{67}$ This was done to enable comparisons with results provided by other registries of the world. A check for multiple primaries was done, according to the rules set by the International Agency for Research on Cancer (IARC). ${ }^{8}$ The population denominators were based on the population structure of Lahore, as provided in table 1 , and computed using the average annual growth rate of $3.46 \%$ made available by the Government of Pakistan. ${ }^{9}$ The average annual population of Lahore was estimated at 9.8 million during these 3 years of study. Counts and age-standardised incidence rates (ASIR) were calculated for each of the three age categories under review and subsequently for 5-year age groups within the adult category. The ASIRs were computed using the World Standard of Segi as the standard population, by applying the direct method of age standardisation and all the rates presented as per 100000 population. ${ }^{10}$ Patients were followed up between July and October 2015, by making telephone calls to them on the numbers provided on their data collection forms. The purpose of calling them was to find their status-alive/dead. However, contact could be established with $60 \%$ of the cases only. ${ }^{4}$ As for the rest, they either did not answer or their SIMS were blocked and if anyone did answer, they said they did not know the concerned person/patient. Data were analysed using Microsoft Excel V.2010 and SPSS V.19. The Institutional Review Board (IRB) of the Shaukat Khanum Memorial Cancer Hospital \& Research Center granted exemption from full IRB evaluation of this study. In this manuscript, the term 'Lahore' refers to the Lahore district and the 'Registry' refers to the PCR.

Table 1 Population estimates for the district of Lahore by gender and age group, 2010-2012

\begin{tabular}{|c|c|c|c|c|c|c|c|c|}
\hline $\begin{array}{l}\text { Year } \rightarrow \\
\begin{array}{l}\text { Age group } \\
\text { (years) }\end{array}\end{array}$ & \multicolumn{2}{|c|}{2010} & \multicolumn{2}{|c|}{2011} & \multicolumn{2}{|c|}{2012} & \multicolumn{2}{|c|}{ Total } \\
\hline $5-9$ & 621343 & 661178 & 642841 & 684055 & 665083 & 707723 & 1929267 & 2052956 \\
\hline $10-14$ & 603207 & 648088 & 624077 & 670512 & 645671 & 693712 & 1872955 & 2012312 \\
\hline $25-29$ & 352415 & 401889 & 364609 & 415794 & 377225 & 430181 & 1094249 & 1247864 \\
\hline $30-34$ & 299024 & 347491 & 309370 & 359514 & 320074 & 371954 & 928468 & 1078959 \\
\hline $35-39$ & 242033 & 285887 & 250407 & 295779 & 259071 & 306013 & 751511 & 887679 \\
\hline $40-44$ & 208009 & 250761 & 215206 & 259437 & 222652 & 268414 & 645868 & 778612 \\
\hline 60-64 & 82959 & 102349 & 85829 & 105891 & 88799 & 109554 & 257587 & 317794 \\
\hline 65-69 & 50387 & 62312 & 52130 & 64468 & 53934 & 66699 & 156450 & 193480 \\
\hline $70-74$ & 40733 & 54305 & 42143 & 56184 & 43601 & 58128 & 126477 & 168616 \\
\hline $75+$ & 44426 & 56267 & 45963 & 58214 & 47553 & 60229 & 137942 & 174710 \\
\hline All ages & 4497552 & 5006319 & 4653167 & 5179538 & 4814167 & 5358750 & 13964885 & 15544606 \\
\hline
\end{tabular}




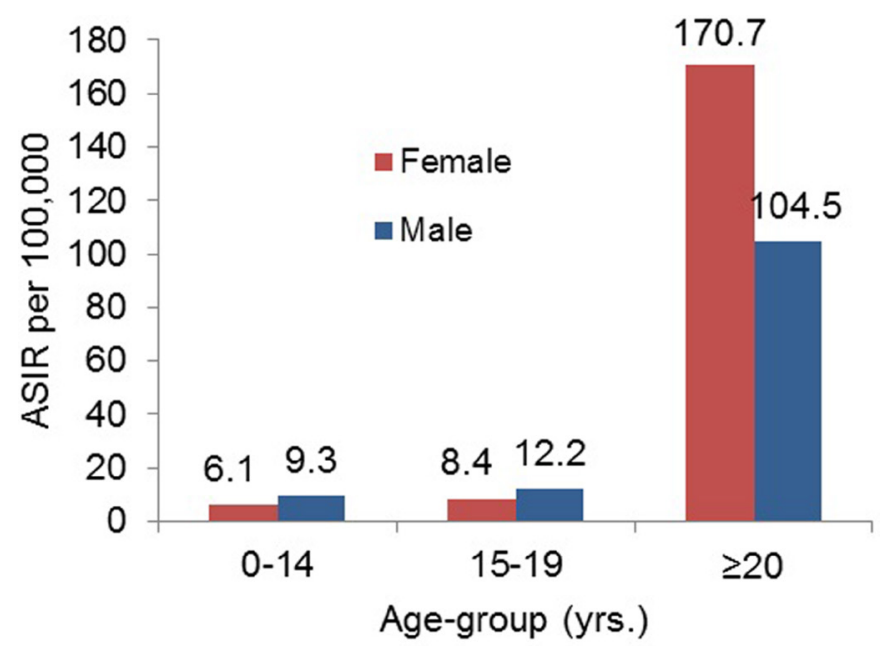

Figure 1 Age-standardised incidence rates (ASIR) by age group and gender, in the Lahore district, Pakistan, 20102012.

\section{RESULTS}

Of a total of 15825 patients newly diagnosed with malignancies in Lahore in 3years' time from 2010 to 2012, $57.3 \%$ were female and $42.7 \%$ were male. The age distribution of the entire cohort of 15825 patients was as follows: mean $48.6 \pm 18.2$ years, range $0-106$ years and mode 60 years $(881$ patients $(5.6 \%))$. The 25 th percentile was 38 years, 50 th percentile was 50 years and the 75 th percentile was 61 years. Almost $93.5 \%$ were microscopically confirmed as opposed to $6.5 \%$ being non-microscopically confirmed. The total number of malignancies recorded was 15840 , with 15 patients having double primaries. ${ }^{4}$ This accounted for the difference in the numbers of patients and malignancies documented. ${ }^{4}$ Of the 15840 cases, $9069(57.3 \%)$ were diagnosed in female and $6771(42.7 \%)$ in male patients. The female-to-male ratio among children was $0.46: 1$, in adolescents $0.48: 1$ and in adults 1.07:1. Among females, the three highest ASIRs according to age group and subcategory of tumours were: in children: lymphoid leukaemia (1.6) and bone, eye and brain and other central nervous system (CNS) tumours (0.5 each); in adolescents: bone tumours (1.4), brain and other CNS tumours (0.9) and ovary (0.8); and in adults: cancers of the breast (79.2), ovary (7.9) and corpus uteri (6.1). Among males, the highest ASIRs were: in children: lymphoid leukaemia (2.7), Hodgkin lymphoma (1.1) and brain and other CNS tumours (0.8); in young adults: bone (2.4), non-Hodgkin lymphoma (NHL (1.3)) and brain and other CNS tumours (1.2); and in adults: cancers of the prostate (10.7), bladder (8.4) and trachea, bronchus and lung (7.7). The proportional distribution of paediatric embryonal tumours was: retinoblastoma $5.5 \%$, neuroblastoma $2.7 \%$, rhabdomyosarcoma $2.1 \%$ (0-14 years) and 5.2\% (15-19 years) and nephroblastoma $2.7 \%$. The ASIR for the entire 0-19year group was also computed, and it was 6.6 for female and 9.9 for male patients. Figures 1-3 and tables 2 and 3 display the ASIRs by gender, age group and cancer type. Within

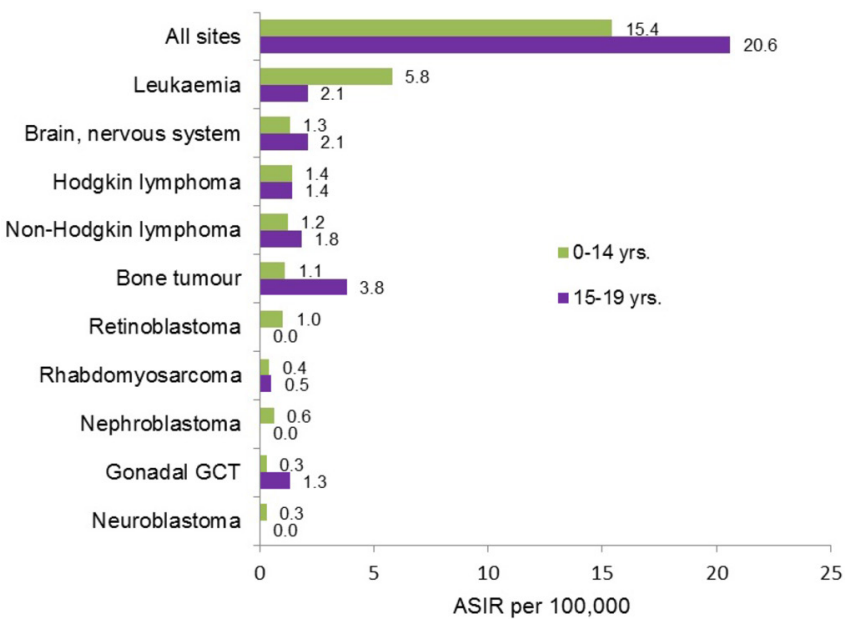

Figure 2 Age-standardised incidence rates (ASIR) in children and adolescents, in the Lahore district, Pakistan, 2010-2012. GCT, germ cell tumour.

tables 2 and 3, incidence rates based on fewer than 10 cases are shown in italics following IARC Cancer Incidence in Five Continents (CI5) practice to indicate unstable incidence rates. Tables 4 and 5 display the 5 -year age-specific incidence rates in adults by cancer type, for females and males, respectively. Table 6 shows a comparison of our results with the incidence rates stated in different studies conducted in Pakistan and New Delhi according to three broad age categories, table 7 shows a comparison of our results with those reported in America and Bangladesh in children and young adults, while online supplementary appendix A shows a comparison of our results in

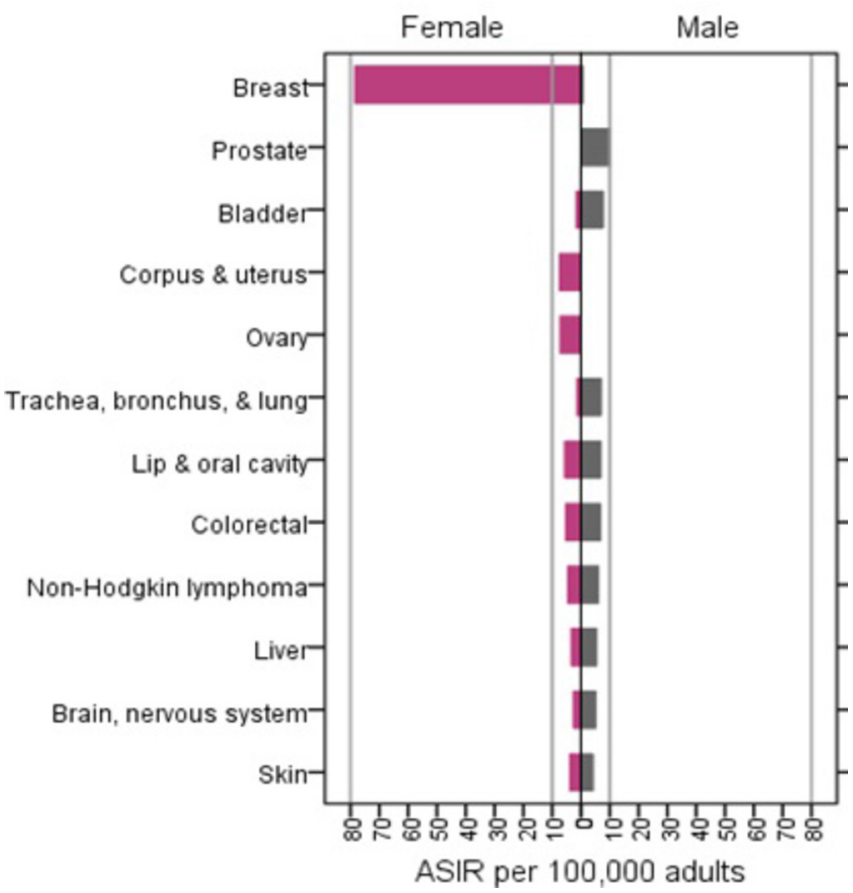

Figure 3 Age-standardised incidence rates (ASIR) by gender among adults, in the Lahore district, Pakistan, 20102012. 
Open Access

Table 2 Age-standardised incidence rates (ASIR) among females, by age group, in the Lahore district, Pakistan, 2010-2012

\begin{tabular}{|c|c|c|c|c|c|c|}
\hline Site (females) & $\begin{array}{l}\text { Count } \\
0-14 \text { years }\end{array}$ & $\begin{array}{l}\text { ASIR } \\
0-14 \text { years }\end{array}$ & $\begin{array}{l}\text { Count } \\
15-19 \text { years }\end{array}$ & $\begin{array}{l}\text { ASIR } \\
15-19 \text { years }\end{array}$ & $\begin{array}{l}\text { Count } \\
\geq 20 \text { years }\end{array}$ & $\begin{array}{l}\text { ASIR } \\
\geq 20 \text { years }\end{array}$ \\
\hline Lip & 0 & 0.0 & 0 & 0.0 & 9 & 0.2 \\
\hline Tongue & 0 & 0.0 & 0 & 0.0 & 129 & 2.8 \\
\hline Mouth & 0 & 0.0 & 3 & 0.2 & 127 & 2.6 \\
\hline Salivary glands & 1 & 0.0 & 0 & 0.0 & 40 & 0.7 \\
\hline Tonsil & 0 & 0.0 & 0 & 0.0 & 8 & 0.2 \\
\hline Nasopharynx & 1 & 0.0 & 2 & 0.1 & 16 & 0.3 \\
\hline Hypopharynx & 0 & 0.0 & 1 & 0.1 & 31 & 0.6 \\
\hline Pharynx & 1 & 0.0 & 0 & 0.0 & 4 & 0.1 \\
\hline Oesophagus & 0 & 0.0 & 1 & 0.1 & 94 & 2.0 \\
\hline Stomach & 0 & 0.0 & 0 & 0.0 & 105 & 2.1 \\
\hline Small intestine & 0 & 0.0 & 0 & 0.0 & 17 & 0.4 \\
\hline Colon & 1 & 0.0 & 5 & 0.3 & 153 & 3.1 \\
\hline Rectum & 1 & 0.0 & 4 & 0.2 & 132 & 2.5 \\
\hline Anus & 0 & 0.0 & 0 & 0.0 & 23 & 0.4 \\
\hline Liver & 3 & 0.1 & 1 & 0.1 & 173 & 4.0 \\
\hline Gall bladder and so on & 0 & 0.0 & 1 & 0.1 & 138 & 3.2 \\
\hline Pancreas & 0 & 0.0 & 1 & 0.1 & 39 & 0.9 \\
\hline Other ill-defined digestive & 1 & 0.0 & 1 & 0.1 & 12 & 0.2 \\
\hline Nose, sinuses & 1 & 0.0 & 2 & 0.1 & 24 & 0.5 \\
\hline Larynx & 0 & 0.0 & 0 & 0.0 & 28 & 0.6 \\
\hline Trachea, bronchus and lung & 2 & 0.0 & 3 & 0.2 & 87 & 2.0 \\
\hline Other thoracic organs & 0 & 0.0 & 1 & 0.1 & 15 & 0.3 \\
\hline Bone & 29 & 0.5 & 22 & 1.4 & 40 & 0.5 \\
\hline Melanoma of the skin & 0 & 0.0 & 0 & 0.0 & 13 & 0.2 \\
\hline Other skin & 1 & 0.0 & 2 & 0.1 & 193 & 4.4 \\
\hline Connective and soft tissue & 19 & 0.3 & 9 & 0.6 & 80 & 1.4 \\
\hline Breast & 3 & 0.0 & 2 & 0.1 & 4077 & 79.2 \\
\hline Vulva & 1 & 0.0 & 0 & 0.0 & 18 & 0.4 \\
\hline Vagina & 0 & 0.0 & 0 & 0.0 & 16 & 0.3 \\
\hline Cervix uteri & 0 & 0.0 & 0 & 0.0 & 247 & 4.8 \\
\hline Corpus uteri & 0 & 0.0 & 0 & 0.0 & 267 & 6.1 \\
\hline Uterus, unspecified & 0 & 0.0 & 0 & 0.0 & 89 & 1.9 \\
\hline Ovary & 12 & 0.2 & 13 & 0.8 & 417 & 7.9 \\
\hline Other female genital organs & 0 & 0.0 & 0 & 0.0 & 18 & 0.4 \\
\hline Placenta & 0 & 0.0 & 0 & 0.0 & 7 & 0.1 \\
\hline Kidney & 15 & 0.3 & 0 & 0.0 & 87 & 1.7 \\
\hline Renal pelvis & 0 & 0.0 & 0 & 0.0 & 1 & 0.0 \\
\hline Ureter & 0 & 0.0 & 0 & 0.0 & 1 & 0.0 \\
\hline Bladder & 1 & 0.0 & 1 & 0.1 & 107 & 2.4 \\
\hline Eye & 23 & 0.5 & 0 & 0.0 & 17 & 0.4 \\
\hline Brain, nervous system & 32 & 0.5 & 14 & 0.9 & 181 & 3.3 \\
\hline Thyroid & 2 & 0.0 & 3 & 0.2 & 210 & 3.5 \\
\hline Adrenal & 2 & 0.0 & 0 & 0.0 & 2 & 0.0 \\
\hline Hodgkin lymphoma & 16 & 0.3 & 7 & 0.4 & 57 & 0.9 \\
\hline
\end{tabular}


Table 2 Continued

\begin{tabular}{|c|c|c|c|c|c|c|}
\hline Site (females) & $\begin{array}{l}\text { Count } \\
0-14 \text { years }\end{array}$ & $\begin{array}{l}\text { ASIR } \\
0-14 \text { years }\end{array}$ & $\begin{array}{l}\text { Count } \\
15-19 \text { years }\end{array}$ & $\begin{array}{l}\text { ASIR } \\
15-19 \text { years }\end{array}$ & $\begin{array}{l}\text { Count } \\
\geq 20 \text { years }\end{array}$ & $\begin{array}{l}\text { ASIR } \\
\geq 20 \text { years }\end{array}$ \\
\hline Non-Hodgkinlymphoma & 18 & 0.3 & 8 & 0.5 & 251 & 5.3 \\
\hline Lymphoid leukaemia & 89 & 1.6 & 5 & 0.3 & 18 & 0.3 \\
\hline Myeloid leukaemia & 13 & 0.2 & 4 & 0.2 & 45 & 0.7 \\
\hline Leukaemia, unspecified & 21 & 0.4 & 5 & 0.3 & 14 & 0.2 \\
\hline Other and unspecified & 17 & 0.3 & 3 & 0.2 & 516 & 10.8 \\
\hline Benign CNS & 12 & 0.2 & 12 & 0.7 & 164 & 2.8 \\
\hline All sites (n (\%)) & $339(3.7 \%)$ & 6.1 & $136(1.5 \%)$ & 8.4 & $8594(94.7 \%)$ & 170.7 \\
\hline
\end{tabular}

Incidence rates based on fewer than 10 cases are shown in italics following IARC Cancer Incidence in Five Continents (CI5) practice to indicate unstable incidence rates.

CNS, central nervous system.

four groups within the age band of 50-69years with those reported by two registries in India and in the UK.

Nearly $27.5 \%$ of the 15825 patients were alive by the cut-off date for this study, approximately $32.4 \%$ had died and the vital status of about $40.1 \%$ could not be determined. Of the 5134 deaths recorded, $5.7 \%$ were reported in children, $2.3 \%$ in young adults and $92.1 \%$ in adults.

\section{DISCUSSION}

In our study, the ASIR was higher in adult women than in men, but it was lower in girls and young women than their corresponding male counterparts. Leukaemia was the most common diagnosis in children and bone tumour in young adults, regardless of gender. Among women, breast cancer and, in men, prostate cancer, were the leading cancer types, in adults. Furthermore, more than $90 \%$ of the cancers were recorded in adults again reinforcing the fact that cancer is primarily a disease of the older people; over $50 \%$ of the cases were diagnosed in patients 50 years of age and above. This scenario is different from what has been observed in the UK, where more than half of all cancer cases each year were diagnosed in people aged 70 years and over, in 2011-2013. ${ }^{11}$ Moreover, in our study, cancers in children accounted for about $5.6 \%$ of the cases, but in the UK, these accounted for less than $1 \%$ of all new cancer cases each year, 2011-2013. ${ }^{11}$ Both in the UK and our study, leukaemia was the most commonly diagnosed cancer in children, while leukaemia, lymphoma, brain and other CNS tumours together accounted for more than two-thirds of all cancers diagnosed in children. ${ }^{11}$ In the UK, cancer in teenagers and young adults accounted for less than $1 \%$ of all new cancer cases, but in our study, cancer in children and adolescents accounted for $7.8 \%$ of all diagnoses, higher than what has been reported in the UK. ${ }^{11}$ This may be attributed to a difference in the characteristics of the UK population from that of the Lahore population. The UK has an ageing population and a comparison of the population distributions for the
UK to the Lahore district population has been made: for ages $0-15$ years: $19 \%$ versus $40 \%$; for ages $16-64$ years: $64 \%$ versus $57 \%$ and for ages 65 years and more: $18 \%$ versus $3 \%$, respectively. ${ }^{12} \mathrm{~A}$ study recently published from Bangladesh has shown that, during 2011-2014, among children, leukaemias, retinoblastoma and malignant bone tumours were the most commonly diagnosed cancers, whereas in adolescents, malignant bone tumours, germ cell and gonadal tumours and epithelial tumours were the three most common cancer types. ${ }^{13}$ However, the ASIRs reported in the aforesaid study from Bangladesh are low as compared with our study; these are, per 100000 population, 0.78 versus 15.4 , respectively, for the age group of $0-14$ years and 0.21 versus 20.6, respectively, for the age group of 15-19years for all sites combined. Another study reporting the findings from different regions of India has shown that, in New Delhi, the ASIR for females was 7.6 and for males 14.6, per 100000 population, in the age group of $0-14$ years during 1978-2002. ${ }^{14}$ These figures are somewhat different from what has been reported in our study, which is 6.1 for girls and 9.3 for boys. The ASIRs per 100000 for New Delhi and Lahore for leukaemia among girls were 2.26 and 2.2, respectively, and among boys 5.11 and 3.6, respectively; these are more similar than different from one another. In New Delhi, following leukaemia, high ASIRs were recorded for brain and other CNS tumours (1.09) and kidney tumours (0.64) among girls, whereas, among boys, for lymphomas (2.5) and brain and other CNS tumours (1.5). The reports from Bangladesh and New Delhi provide the incidence rates per million population. However, in order to make comparisons with our study, these have been presented as per 100000 population.

Further comparison of the incidence rates obtained in our study has been made with those provided by two other studies conducted in Lahore and with one conducted in the Karachi South district, which was part of the Karachi Cancer Registry (KCR). The studies conducted in Lahore, 
Open Access

Table 3 Age-standardised incidence rates (ASIR) among males, by age group, in the Lahore district, Pakistan, 2010-2012

\begin{tabular}{|c|c|c|c|c|c|c|}
\hline Site (males) & $\begin{array}{l}\text { Count } \\
0-14 \text { years }\end{array}$ & $\begin{array}{l}\text { ASIR } \\
0-14 \text { years }\end{array}$ & $\begin{array}{l}\text { Count } \\
15-19 \text { years }\end{array}$ & $\begin{array}{l}\text { ASIR } \\
15-19 \text { years }\end{array}$ & $\begin{array}{l}\text { Count } \\
\geq 20 \text { years }\end{array}$ & $\begin{array}{l}\text { ASIR } \\
\geq 20 \text { years }\end{array}$ \\
\hline Lip & 0 & 0.0 & 0 & 0.0 & 13 & 0.2 \\
\hline Tongue & 0 & 0.0 & 0 & 0.0 & 180 & 3.0 \\
\hline Mouth & 2 & 0.0 & 0 & 0.0 & 210 & 3.6 \\
\hline Salivary glands & 2 & 0.0 & 1 & 0.1 & 47 & 0.8 \\
\hline Tonsil & 0 & 0.0 & 0 & 0.0 & 8 & 0.1 \\
\hline Other oropharynx & 0 & 0.0 & 0 & 0.0 & 6 & 0.1 \\
\hline Nasopharynx & 0 & 0.0 & 2 & 0.1 & 17 & 0.3 \\
\hline Hypopharynx & 0 & 0.0 & 0 & 0.0 & 21 & 0.4 \\
\hline Pharynx & 0 & 0.0 & 0 & 0.0 & 5 & 0.1 \\
\hline Oesophagus & 0 & 0.0 & 1 & 0.1 & 126 & 2.3 \\
\hline Stomach & 1 & 0.0 & 0 & 0.0 & 161 & 2.7 \\
\hline Small intestine & 0 & 0.0 & 0 & 0.0 & 26 & 0.4 \\
\hline Colon & 1 & 0.0 & 7 & 0.4 & 222 & 3.9 \\
\hline Rectum & 0 & 0.0 & 7 & 0.4 & 179 & 3.0 \\
\hline Anus & 0 & 0.0 & 2 & 0.1 & 39 & 0.6 \\
\hline Liver & 1 & 0.0 & 1 & 0.1 & 326 & 6.1 \\
\hline Gall bladder and so on & 0 & 0.0 & 1 & 0.1 & 92 & 1.7 \\
\hline Pancreas & 0 & 0.0 & 0 & 0.0 & 57 & 1.1 \\
\hline Other ill-defined digestive & 0 & 0.0 & 0 & 0.0 & 16 & 0.3 \\
\hline Nose, sinuses & 1 & 0.0 & 2 & 0.1 & 29 & 0.5 \\
\hline Larynx & 0 & 0.0 & 0 & 0.0 & 183 & 3.4 \\
\hline Trachea, bronchus and lung & 0 & 0.0 & 0 & 0.0 & 396 & 7.7 \\
\hline Other thoracic organs & 2 & 0.0 & 1 & 0.1 & 23 & 0.4 \\
\hline Bone & 38 & 0.6 & 42 & 2.4 & 63 & 0.9 \\
\hline Melanoma of the skin & 1 & 0.0 & 1 & 0.1 & 11 & 0.2 \\
\hline Other skin & 8 & 0.1 & 4 & 0.2 & 259 & 4.6 \\
\hline Connective and soft tissue & 21 & 0.4 & 15 & 0.9 & 108 & 1.6 \\
\hline Breast & 0 & 0.0 & 1 & 0.1 & 69 & 1.3 \\
\hline Penis & 0 & 0.0 & 0 & 0.0 & 1 & 0.0 \\
\hline Prostate & 0 & 0.0 & 0 & 0.0 & 526 & 10.7 \\
\hline Testis & 4 & 0.1 & 9 & 0.5 & 77 & 0.9 \\
\hline Other male genital organs & 1 & 0.0 & 0 & 0.0 & 4 & 0.1 \\
\hline Kidney & 17 & 0.3 & 2 & 0.1 & 153 & 2.7 \\
\hline Renal pelvis & 0 & 0.0 & 0 & 0.0 & 1 & 0.0 \\
\hline Ureter & 0 & 0.0 & 0 & 0.0 & 1 & 0.0 \\
\hline Bladder & 1 & 0.0 & 0 & 0.0 & 440 & 8.4 \\
\hline Other urinary organs & 0 & 0.0 & 0 & 0.0 & 2 & 0.0 \\
\hline Eye & 27 & 0.5 & 2 & 0.1 & 28 & 0.5 \\
\hline Brain, nervous system & 48 & 0.8 & 20 & 1.2 & 390 & 5.8 \\
\hline Thyroid & 1 & 0.0 & 3 & 0.2 & 77 & 1.2 \\
\hline Adrenal & 1 & 0.0 & 1 & 0.1 & 5 & 0.1 \\
\hline Hodgkin lymphoma & 66 & 1.1 & 17 & 1.0 & 119 & 1.7 \\
\hline Non-Hodgkin lymphoma & 58 & 0.9 & 23 & 1.3 & 412 & 6.8 \\
\hline Multiple myeloma & 1 & 0.0 & 0 & 0.0 & 52 & 0.9 \\
\hline
\end{tabular}


Table 3 Continued

\begin{tabular}{|c|c|c|c|c|c|c|}
\hline Site (males) & $\begin{array}{l}\text { Count } \\
0-14 \text { years }\end{array}$ & $\begin{array}{l}\text { ASIR } \\
0-14 \text { years }\end{array}$ & $\begin{array}{l}\text { Count } \\
15-19 \text { years }\end{array}$ & $\begin{array}{l}\text { ASIR } \\
15-19 \text { years }\end{array}$ & $\begin{array}{l}\text { Count } \\
\geq 20 \text { years }\end{array}$ & $\begin{array}{l}\text { ASIR } \\
\geq 20 \text { years }\end{array}$ \\
\hline Lymphoid leukaemia & 156 & 2.7 & 12 & 0.7 & 39 & 0.6 \\
\hline Other leukaemias & 0 & 0.0 & 0 & 0.0 & 6 & 0.1 \\
\hline Leukaemia, unspecified & 34 & 0.6 & 3 & 0.2 & 23 & 0.3 \\
\hline Benign CNS & 19 & 0.3 & 8 & 0.5 & 155 & 2.1 \\
\hline All sites (n (\%)) & $554(8.1 \%)$ & 9.3 & $210(3.1 \%)$ & 12.2 & $6007(88.7 \%)$ & 104.5 \\
\hline
\end{tabular}

Incidence rates based on fewer than 10 cases are shown in italics following IARC Cancer Incidence in Five Continents (CI5) practice to indicate unstable incidence rates.

CNS, central nervous system .

two in number, were based on cancer incidence in children and adolescents registered at the SKMCH\&RC, Lahore. ${ }^{1516}$ The last report on Karachi South published in the CI5, Volume IX, was based on the 1998-2002 data provided by Dr Yasmin Bhurgri (late) to the agency. ${ }^{17}$ The average annual population of Karachi South was less than half a million. The age-specific rates and the population structure reported in CI5, Volume IX, for Karachi South have been used by the PCR Staff to compute the ASIRs for the Karachi South district according to three age groups under consideration and the top ranking cancers as reported in Lahore to enable a comparison between these two regions of Pakistan. Table 6 shows the details related to the cancers with highest ranking ASIRs seen in Lahore along with corresponding ASIRs obtained from four other studies, including India, where available. The comparison shows that the ASIRs in children were more similar than different from one another except for brain and other CNS tumours and Hodgkin lymphoma, which were relatively high in Karachi South. The incidence of paediatric brain tumours appeared to be comparatively low in Lahore; perhaps not everyone could afford an MRI/CT and some of these kids died before a diagnosis was made or the cases were under-reported. Among adolescents, again, the incidence rates were comparable with aforementioned studies, except for ovarian cancer and NHL having higher ASIRs in Karachi South than in Lahore. A recent report on childhood cancers released by the IARC has shown almost the same results for the 20082012 time period for Lahore district as part of the PCR, as for the 3-year time period on which our study is based. ${ }^{18}$ In table 7, further comparison with the incidence rates reported by the American Cancer Society (ACS) in two different studies shows the rates to be more similar than different from one another except for brain and other CNS tumours, which were noticeably low in our study; for Hodgkin lymphoma, the rate was high in our study in children but low in young adults, and for bone tumour, the rate was substantially high in our study compared with that reported in the ACS studies. ${ }^{19}{ }^{20}$ Table 7 shows the details related to the Bangladesh study, the ACS studies (two in number) and our own study.

Among adult patients, as shown in table 6, all the ASIRs reported for Karachi South were higher than for Lahore, except for brain and other CNS tumours. In adults, breast cancer in females and prostate cancer in males had the highest ASIRs in Lahore. In Karachi South, the ASIR for breast cancer was higher (114.9) than that recorded in Lahore (79.2). In Lahore, the ASIR for prostate cancer was 10.7 and for bladder cancer it was 8.4, among men, compared with 16.8 and 15.4, respectively, in Karachi South. Furthermore, in Karachi South, the highest ASIRs, after breast cancer in women, were recorded for tobacco-related cancers, that is, those of the trachea, bronchus and lung (41.9) and lip and oral cavity (37.2), in men. The ASIR for cancers of the lip and oral cavity were also high (33.7) among women in Karachi South. The point to be noted is that in our previous publication on cancers in the Lahore district, the ASIR for breast cancer in females, for all age groups combined, ${ }^{4}$ was reported to be 47.6, while in the current study, stratification by age group has shown the ASIR to be 79.2 among adult women. The relatively high ASIR for breast cancer is intriguing as no definite risk factors have been identified so far. An epidemiological, retrospective study on breast cancer at a cancer treatment facility in Lahore has shown that most women were parous, had breast fed their babies, had not used any oral contraceptives or hormone replacement therapy and there was no noteworthy difference in the premenopausal and postmenopausal status. A family history of cancer was present in less than one-fifths of the patients. ${ }^{21}$ Furthermore, these females had a relatively low mean presenting age ( 48 years), age at menarche was 13.2 years, age at first childbirth was 23.7 years and the body mass index (BMI) was on the higher side..$^{21}$ The vast majority of cancers appeared to be sporadic in nature, while a lower age at menarche and a higher BMI appeared to be striking. ${ }^{21}$ Although the findings of various studies including case-control studies have not been consistent with one another, it has been demonstrated that factors as 


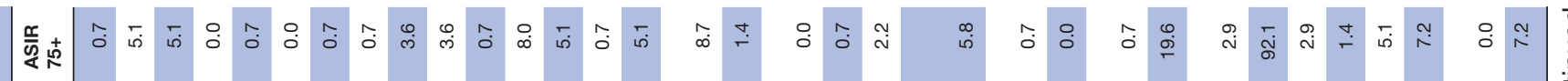
喜去

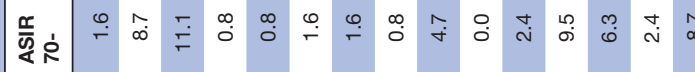

₹

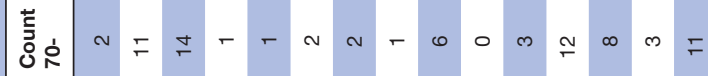

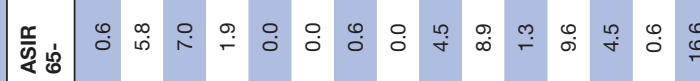

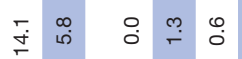

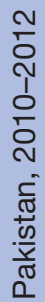

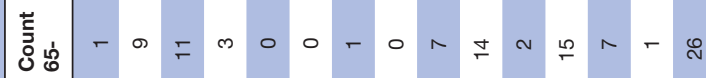

$\approx$

造察

$\stackrel{\infty}{\infty} \infty$

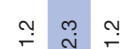

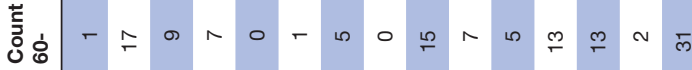

$\stackrel{m}{\sim}$

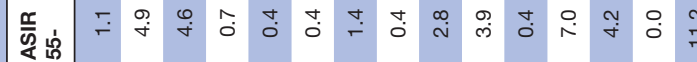

$\hat{i} \bar{i}$

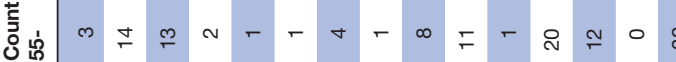

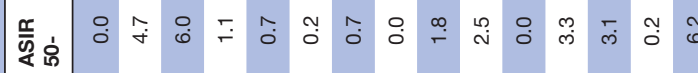

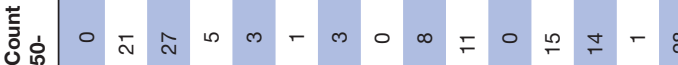

우웅

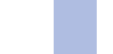

$\infty$

爵

落

呚字

웅영

$\stackrel{\leftrightarrow}{\circ} \hat{0} \stackrel{m}{\leftarrow}$

$\stackrel{\infty}{0} \stackrel{\infty}{\circ} \stackrel{\infty}{-}$

$\infty$

A

$\circ \circ 0$

悉察

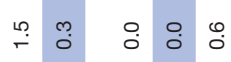

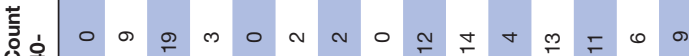

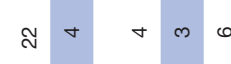

$\infty$

$-2-\frac{1}{2}$

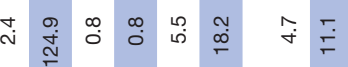

爱它

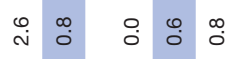

$\underset{\infty}{\infty} \stackrel{\circ}{\circ}:$

잉

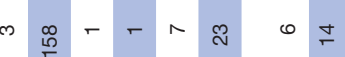

$\pm$

$\stackrel{+}{\dot{0}}$ :

$\stackrel{m}{+}$

$\stackrel{\infty}{+}$

$\stackrel{\infty}{\circ} \stackrel{\circ}{\circ} \stackrel{+}{\circ}$

$\circ$ a

N

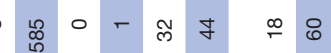

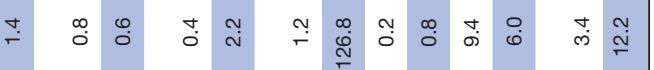

爱息

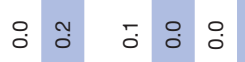

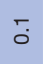

$\stackrel{0}{\circ}$

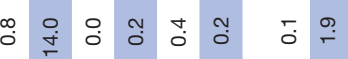

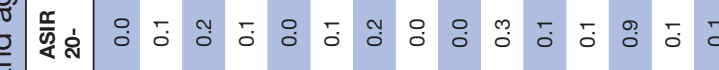

䓊

ชั่ ลे 


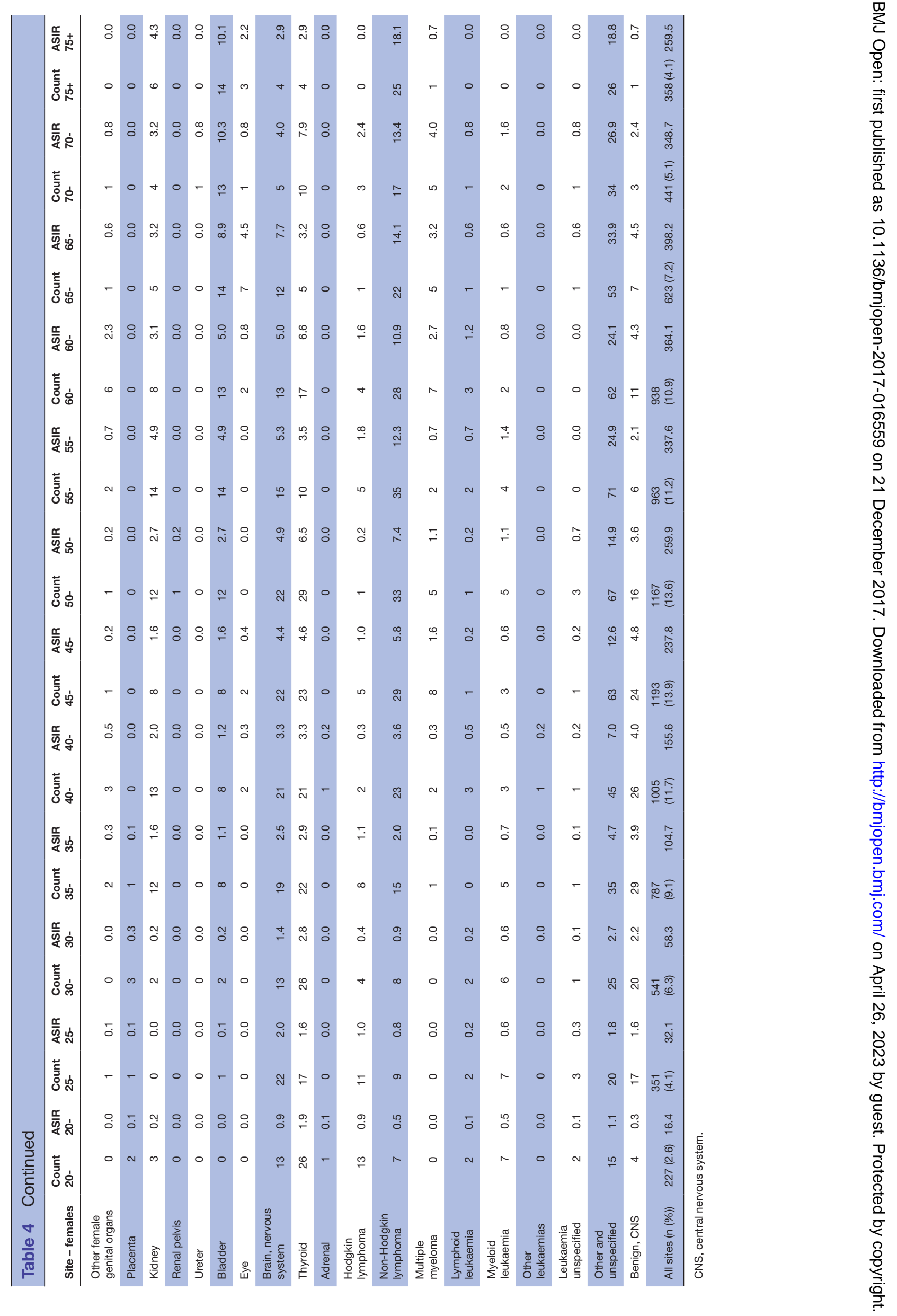




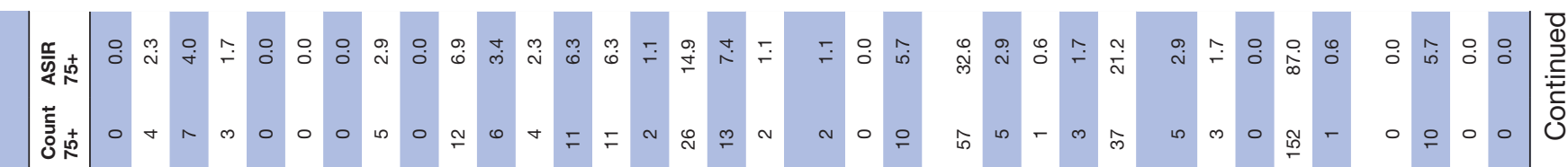

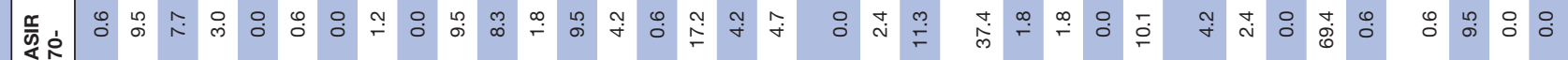

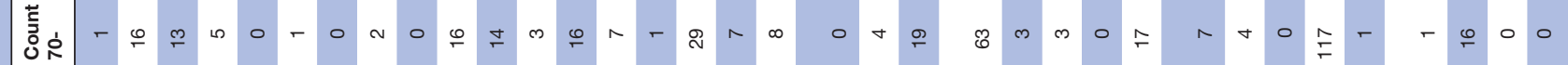
秀安

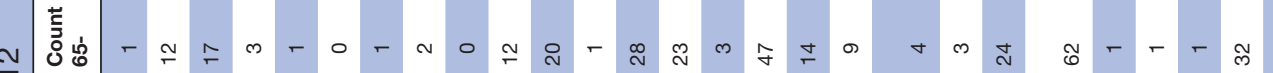

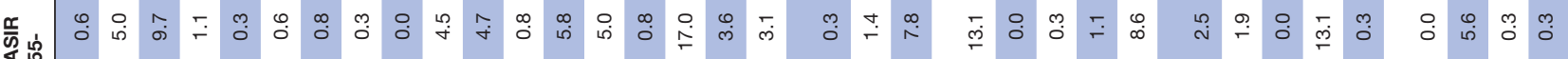
喜 言崫 N 需官

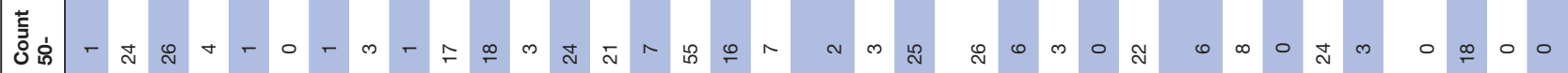

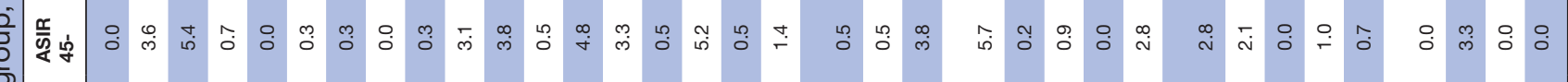
芦字 秀

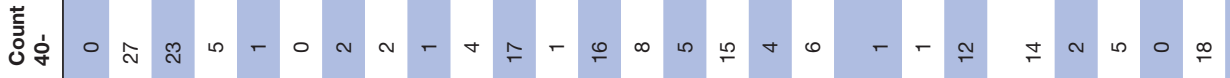

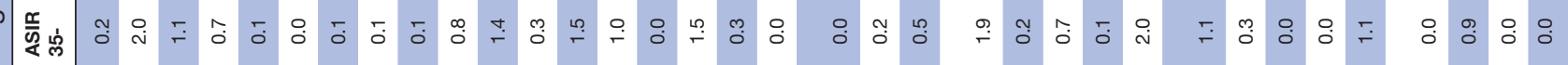

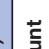

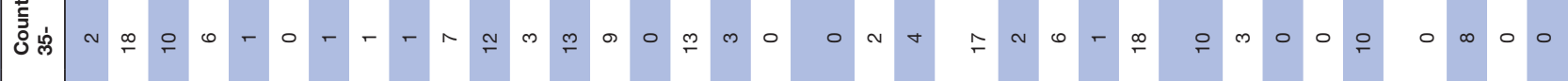

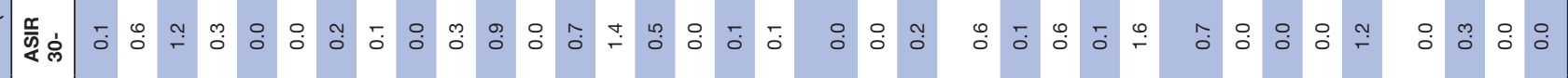
鸷爱

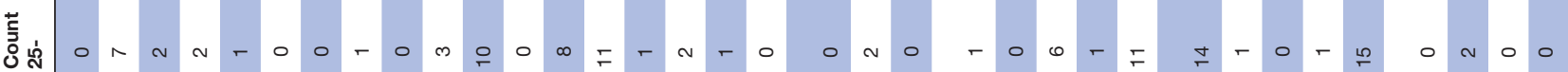

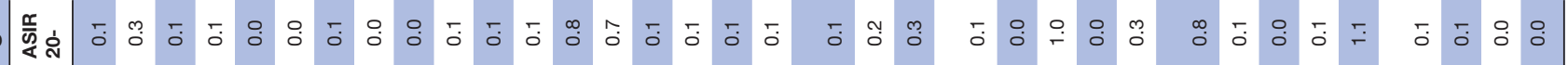

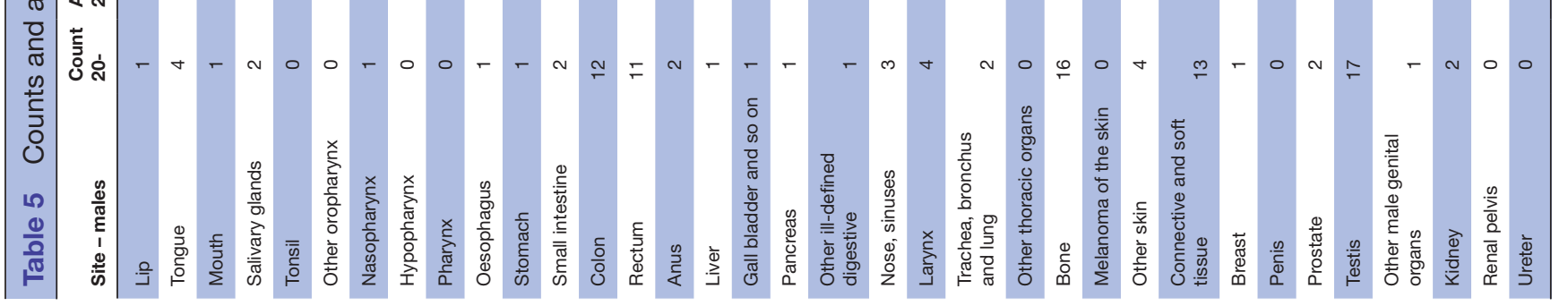




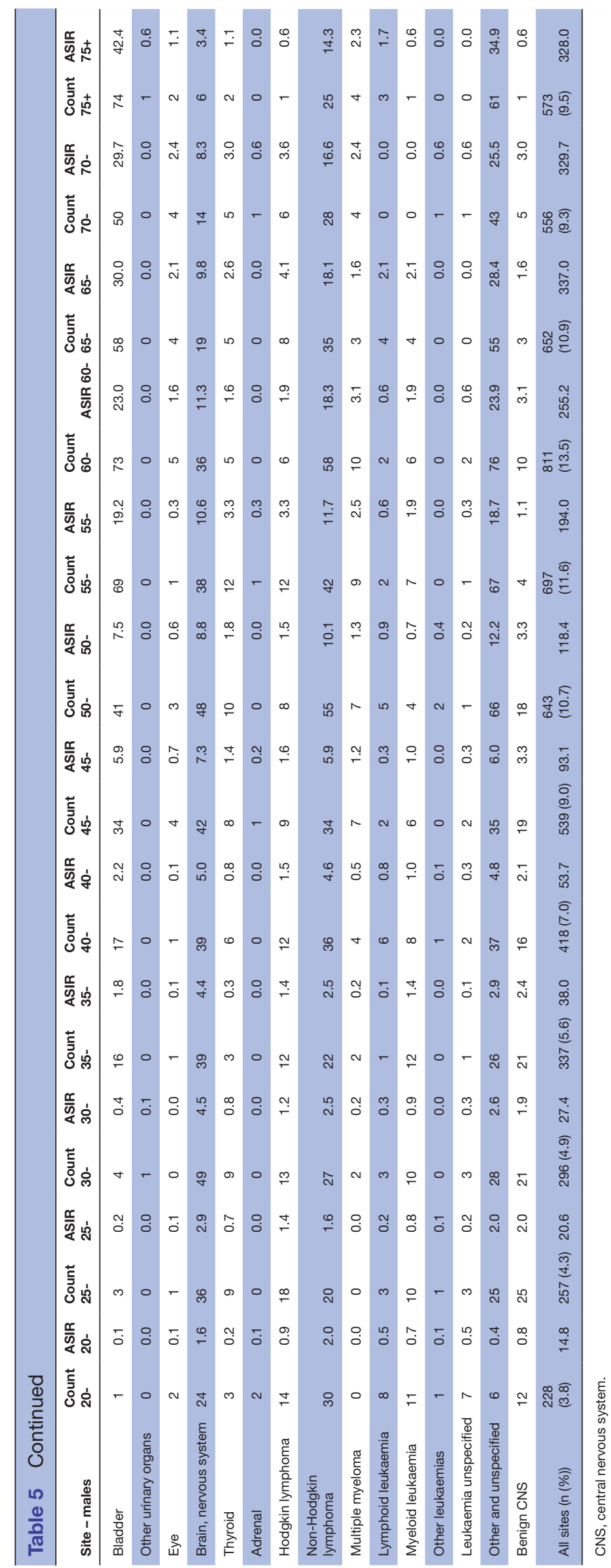


Table 6 ASIRs per 100000 population, as reported in other studies conducted in Pakistan and in New Delhi, India

\begin{tabular}{|c|c|c|c|c|c|c|c|c|c|c|c|}
\hline \multirow[b]{3}{*}{ Age group } & \multirow[b]{3}{*}{ Cancer type/site } & \multicolumn{8}{|c|}{ Pakistan } & \multirow{2}{*}{\multicolumn{2}{|c|}{$\begin{array}{l}\text { India } \\
\\
\text { 1978-2002: } \\
\text { New Delhi }\end{array}$}} \\
\hline & & \multicolumn{2}{|c|}{$\begin{array}{l}\text { PCR } \\
\text { 2010-2012: } \\
\text { Lahore } \\
\text { district }\end{array}$} & \multicolumn{2}{|c|}{$\begin{array}{l}\text { Badar } \\
\text { et al 2015: } \\
\text { SKMCH\&RC, } \\
\text { Lahore }\end{array}$} & \multicolumn{2}{|c|}{$\begin{array}{l}\text { Badar } \\
\text { et al 2008: } \\
\text { SKMCH\&RC, } \\
\text { Lahore }\end{array}$} & \multicolumn{2}{|c|}{$\begin{array}{l}\text { KCR } \\
\text { 1998-2002: } \\
\text { Karachi South } \\
\text { district }\end{array}$} & & \\
\hline & & $\mathrm{F}$ & M & $\mathrm{F}$ & M & $\mathrm{F}$ & M & $\mathrm{F}$ & M & $\mathrm{F}$ & M \\
\hline \multirow[t]{10}{*}{$0-14$ years } & Lymphoid leukaemia & 1.6 & 2.7 & 1.5 & 2 & 0.5 & 0.7 & 1.4 & 3.0 & 1.5 & 3.8 \\
\hline & Brain, nervous system & 0.5 & 0.8 & 1 & 1 & 0.3 & 0.7 & 1.3 & 1.5 & 1.1 & 1.5 \\
\hline & Bone & 0.5 & 0.6 & 0.4 & 0.4 & 0.3 & 0.4 & 0.7 & 0.6 & 0.6 & 0.8 \\
\hline & Eye & 0.5 & 0.5 & 0.4 & 0.6 & 0.2 & 0.3 & 0.3 & 0.4 & 0.4 & 0.8 \\
\hline & Leukaemia, unspecified & 0.4 & 0.6 & 0.3 & 0.5 & 0.1 & 0.3 & 0.2 & 0.1 & 0.4 & 0.6 \\
\hline & Connective and soft tissue & 0.3 & 0.4 & 0.2 & 0.3 & 0.2 & 0.4 & 0.3 & 0.4 & 0.5 & 0.7 \\
\hline & Non-Hodgkin lymphoma & 0.3 & 0.9 & 0.4 & 0.7 & 0.3 & 0.9 & 0.8 & 1.2 & 0.4 & 1.3 \\
\hline & Hodgkin lymphoma & 0.3 & 1.1 & 0.2 & 0.9 & 0.2 & 0.4 & 0.5 & 1.4 & 0.1 & 1.3 \\
\hline & Kidney & 0.3 & 0.3 & 0.1 & 0.5 & 0.3 & 0.3 & 0.3 & 0.5 & 0.6 & 0.9 \\
\hline & Myeloid leukaemia & 0.2 & 0.3 & 0 & 0.1 & 0.1 & 0 & 0.2 & 0.9 & 0.4 & 0.7 \\
\hline \multirow[t]{12}{*}{ 15-19years } & Bone & 1.4 & 2.4 & 1 & 2 & - & - & 3.3 & 2.4 & - & - \\
\hline & Brain, nervous system & 0.9 & 1.2 & 1.7 & 1.9 & - & - & 1.6 & 2.2 & - & - \\
\hline & Ovary & 0.8 & - & 0.2 & - & - & - & 1.9 & - & - & - \\
\hline & Connective and soft tissue & 0.6 & 0.9 & 1 & 1.3 & - & - & 0.5 & 1.8 & - & - \\
\hline & Colon, rectum and anus & 0.5 & 0.9 & - & - & - & - & 1.2 & 1.2 & - & - \\
\hline & Non-Hodgkin lymphoma & 0.5 & 1.3 & 0.7 & 1.3 & - & - & 2.1 & 4.2 & - & - \\
\hline & Hodgkin lymphoma & 0.4 & 1 & 1.2 & 1.3 & - & - & 0.5 & 0.8 & - & - \\
\hline & Lymphoid leukaemia & 0.3 & 0.9 & 0.3 & 0.2 & - & - & 0.7 & 2 & - & - \\
\hline & Leukaemia, unspecified & 0.3 & 0.2 & 0.3 & 0.3 & - & - & 0.9 & 0.8 & - & - \\
\hline & Myeloid leukaemia & 0.2 & 0.4 & 0.2 & 0 & - & - & 2.6 & 2.2 & - & - \\
\hline & Testis & - & 0.7 & - & 0.6 & - & - & - & 1 & - & - \\
\hline & Skin & 0.1 & 0.3 & 0 & 0 & - & - & - & 0.4 & - & - \\
\hline \multirow[t]{15}{*}{$\geq 20$ years } & Breast & 79.2 & 1.3 & - & - & - & - & 114.9 & 1.6 & - & - \\
\hline & Ovary & 7.9 & - & - & - & - & - & 14.1 & - & - & - \\
\hline & Lip and oral cavity & 6.3 & 7.6 & - & - & - & - & 33.7 & 37.2 & - & - \\
\hline & Corpus uteri & 6.1 & - & - & - & - & - & 11.1 & - & - & - \\
\hline & Colon, rectum and anus & 6 & 7.5 & - & - & - & - & 7.8 & 10.6 & - & - \\
\hline & Non-Hodgkin lymphoma & 5.3 & 6.8 & - & - & - & - & 7.7 & 11.4 & - & - \\
\hline & Cervix uteri & 4.8 & - & - & - & - & - & 12.5 & - & - & - \\
\hline & Other skin & 4.4 & 4.8 & - & - & - & - & 6.9 & 7.1 & - & - \\
\hline & Liver & 4 & 6.1 & - & - & - & - & 6.1 & 8.9 & - & - \\
\hline & Thyroid & 3.5 & 1.2 & - & - & - & - & 4.7 & 1.1 & - & - \\
\hline & Prostate & - & 10.7 & - & - & - & - & - & 16.8 & - & - \\
\hline & Bladder & 2.4 & 8.4 & - & - & - & - & 4.4 & 15.4 & - & - \\
\hline & Trachea, bronchus and lung & 2.0 & 7.7 & - & - & - & - & 5.9 & 41.9 & - & - \\
\hline & Brain, nervous system & 3.3 & 5.8 & - & - & - & - & 3.5 & 4.3 & - & - \\
\hline & Larynx & 0.6 & 3.4 & - & - & - & & 3.0 & 17.9 & - & - \\
\hline
\end{tabular}

ASIRs, age-standardised incidence rates; F, female; KCR, Karachi Cancer Registry; M, male; PCR, Punjab Cancer Registry.

young age at menarche, single marital status, nulliparity, late first full-term pregnancy, use of oral contraceptives, late menopause, high BMI and a family history of breast cancer could be associated with an increased risk, whereas young age at first live birth, increasing parity and vitamin D supplementation could be associated with a decreased 
Table 7 Comparison of the Lahore district ASIRs per 100000 population with those reported for Bangladesh and the USA, as compiled by the American Cancer Society (ACS), in children and adolescents

\begin{tabular}{|c|c|c|c|c|c|c|c|}
\hline \multirow[b]{2}{*}{$\begin{array}{l}\text { Source/region } \rightarrow \\
\text { Year } \rightarrow \\
\text { Cancer type/site } \downarrow\end{array}$} & \multirow[b]{2}{*}{$\begin{array}{l}\text { Lahore } \\
\text { 2010-2012* } \\
\text { ASIR }\end{array}$} & \multicolumn{3}{|l|}{$0-14$ years } & \multicolumn{3}{|l|}{ 15-19years } \\
\hline & & $\begin{array}{l}\text { Bangladesh } \\
2011-2014 \\
\text { ASIR }\end{array}$ & $\begin{array}{l}\text { ACS } \\
2007-2011^{\dagger} \\
\text { ASIR }\end{array}$ & $\begin{array}{l}\text { ACS } \\
2008-2012^{\ddagger} \\
\text { ASIR }\end{array}$ & $\begin{array}{l}\text { Lahore } \\
\text { 2010-2012* } \\
\text { ASIR }\end{array}$ & $\begin{array}{l}\text { Bangladesh } \\
2011-2014 \\
\text { ASIR }\end{array}$ & $\begin{array}{l}\text { ACS } \\
2008-2012^{\ddagger} \\
\text { ASIR }\end{array}$ \\
\hline All ICCC groups & 15.4 & 0.7 & 17.5 & 16.2 & 20.6 & 0.2 & 22.4 \\
\hline Leukaemia & 5.8 & 0.1 & 5.3 & 5.3 & 2.1 & $<0.1$ & 3.3 \\
\hline Brain, nervous system & 1.3 & $<0.1$ & 4.6 & 3.5 & 2.1 & $<0.1$ & 2.2 \\
\hline Rhabdomyosarcoma & 0.4 & - & 0.5 & 0.5 & 0.5 & - & 0.4 \\
\hline Bone tumour§ & 1.1 & $<0.1$ & 0.7 & 0.6 & 3.8 & $<0.1$ & 1.2 \\
\hline Non-Hodgkin lymphoma & 1.2 & - & 1.0 & 0.9 & 1.8 & - & 1.7 \\
\hline Neuroblastoma & 0.3 & $<0.1$ & 1.1 & 1.1 & - & - & $<0.1$ \\
\hline
\end{tabular}

${ }^{*}$ Does not include benign brain tumours.

†Includes benign brain tumours.

¥Excludes benign and borderline brain tumours.

$\S$ Bone tumour includes Ewing sarcoma and osteosarcoma.

ASIRs, age-standardised incidence rates; GCT, germ cell tumour; ICCC, International Classification of Childhood Cancer.

risk of this disease in our population. Large-scale, population-based studies are needed to validate demographic, clinical and lifestyle risk factors related to pathways of this disease including the abovementioned factors. ${ }^{22-26}$

Our literature review did not find any separate results for the broad $\geq 20$-year category by the ACS or the Surveillance, Epidemiology, and End Results (SEER) Program. However, stratification of the data for Lahore for adults by 5-year age group (tables 4 and 5) and further comparisons of the age-specific incidence rates of the commonly diagnosed cancers with what has been reported by IARC in CI5 Volume X and the SEER Program have revealed that, in general, the incidence rates for Lahore were somewhat different from those of New Delhi and Mumbai but markedly different from what has been reported by the SEER Program and the UK (England), with the latter two showing very high incidence rates for almost all cancer types. ${ }^{27} 28$ As for New Delhi and Mumbai, it has been shown that in males, the Lahore district incidence rates for prostate cancer were relatively high in the age groups of 50-54, 55-59, 60-64, 65-69years compared with those for Mumbai but lower than those for New Delhi and markedly low compared with the UK incidence rates. ${ }^{28}$ Online supplementary appendix A shows a comparison of three different types of cancers by region and four aforementioned age groups. Furthermore, the incidence rates for cancers of the trachea, bronchus and lung for Lahore were quite low compared with the aforementioned regions especially the UK, and similar differences were observed for cancers of the oral cavity, colorectum and NHL, in adults in all of the 5-year age categories. Among females, in all age groups in adults, the incidence rates for cancer of the breast were higher than those reported for the Indian registries under discussion except those $75+$ years of age but markedly low compared with the UK rates except the age category of 20-34years, in which the incidence rates were higher than the UK rates. Online supplementary appendix A shows a comparison of some of the age groups for breast cancer by region. Moreover, the incidence rates for cancers of the corpus uteri were high as compared with Mumbai except in those $75+$ years but lower than New Delhi's. Incidence rates for cancers of the ovary, oral cavity and colorectum were low, and for cancer of the cervix uteri, incidence rates were significantly lower than those for the Indian registries studied. The time periods available or used for making comparisons were 2003-2007 for New Delhi, Mumbai and the UK and 2010-2014 for the SEER Program. ${ }^{27} 28$ Finally, a comparison with the age-specific rates for the Karachi South district of Pakistan showed that for the time period 1998-2002, in both male and female patients, the KCR rates were significantly high for the commonly diagnosed cancers including prostate, breast, colorectum, lip and oral cavity, cervix uteri and corpus uteri versus those reported for Lahore. ${ }^{17}$ The differences, although intriguing, have not been fully explored to enable us to comment on them. Extensive population-based studies on risk factors could highlight some of the reasons associated with the differences observed. Although comparisons have been made with the incidence rates reported in other regions of the world, the use of different standard populations, as the Segi World Standard Population in our study and the US 2000 Standard Population by the ACS, indicates a limitation of our report. Furthermore, 
the availability of results from the abovementioned studies for different time periods is also suggestive of a limitation of our review.

\section{Generalisability of the results}

In Pakistan, the last census was held in 1998, and there is an ongoing one this year. In March 1998, the total population of the district of Lahore was recorded to be 6318745 with an intercensal increase of $78.3 \%$ since March 1981 when it was $3544942 .{ }^{9}$ The average annual growth rate of Lahore was nearly $3.5 \%$ during this period. In the 1998 census report, the total area of Lahore was documented as 1772 square kilometres, which gives a population density of 3566 persons per square kilometre as against 2000 persons observed in 1981 , thus indicating a high growth rate of the population. ${ }^{29}$ A comparison of the population density per square kilometre of the Lahore district with other populous districts of Punjab, as reported in 1998, has been made: Gujranwala: 939, Faisalabad: 927, Sialkot: 903 and Multan: 838 persons. ${ }^{29}$ It is, however, noticeable that the land area of these districts is vast as compared with the Lahore district. ${ }^{29}$ The urban population of the Lahore district accounted for $82.4 \%$ of the total population of the district in 1998, which grew at an average rate of 3.3\% during 1981-1998, but the urban population of the province of Punjab was $31.3 \% \cdot{ }^{29}$ Urban population in other provinces of Pakistan was reported as: Sindh: $48.8 \%$, Balochistan: 23.9\% and Khyber Pakhtunkhwa: 16.9\%, according to the 1998 population census. ${ }^{29}$ The differences are stark reflecting that Lahore has had a very high population density for decades, and the ratio of urban to rural population has also remained extremely high for as long. These dissimilarities are meaningful and one can question whether the cancer distributions reported for Lahore can be extrapolated to the inhabitants of other districts of Punjab or to other provinces of the country. Once the latest census findings are released completely and studies on cancer registration conducted in other districts of the region, will we be able to see the actual scenario related to the incidence rates and will hopefully clarify this matter further.

\section{CONCLUSIONS}

In a resource-constrained country like Pakistan, having continued, sustainable reporting and registration of any disease is a challenge. There are, however, significant gains if an accurate and sustainable registry is available for diseases with a significant burden on society. Overall, childhood malignancies are often curable if diagnosed and treated in a timely and appropriate manner, and an accurate estimate of their incidence can help health planners in accurate allocation of resources to treat these.

The PCR and the reports on cancer estimates for Lahore will perhaps bring this neglected disease to the attention of policy makers and guide them about the allocation of healthcare resources to where they are most needed incorporating specialist training, infrastructure availability, development of prevention programmes, establishment of low cost, early detection/diagnosis methods/techniques and research into putative risk factors implicated in the aetiology of the disease. These reports could also motivate and facilitate other professionals to set up registries in their respective regions and promote cancer registration in the country, thereby enabling comparisons of incidence rates with adjacent districts.

Acknowledgements Clinical and participating investigators: Misbah Masood was responsible for reporting the cancers recorded at the Institute of Nuclear Medicine \& Oncology, Lahore; Ghulam Rasool Sial from Ittefaq Hospital, Lahore; Nasir Chughtai from Sheikh Zayed Hospital, Lahore; Omar Rasheed Chughtai from Chughtais Lahore Lab, Lahore; Tanveer Mustafa from Fatima Jinnah Medical University, Lahore; Zeba Aziz and Muhammad Abbas Khokhar from Jinnah Hospital, Lahore; Ghazala Hanif and Alia Ahmad from the Children's Hospital \& the Institute of Child Health, Lahore; Rakhshindah Bajwa from the Services Institute of Medical Sciences, Lahore; Sabiha Riaz and Imrana Tanvir from Fatima Memorial College of Medicine \& Dentistry, Lahore; Farooq Aziz from Shalamar Medical \& Dental College, Lahore; Tazeen Anis from Allama Iqbal Medical College, Lahore; Shahida Niazi from King Edward Medical University, Lahore, and Bilquis A. Suleman from Nawaz Sharif Social Security Hospital, Lahore. Alia Zaidi from St. Jude Children's Research Hospital appraised the article critically for important intellectual content. From SKMCH \& RC: Neelam Siddiqui, Maria Qubtia and Saadiya Javed contributed intellectually to the study; Mohammad Tariq Mahmood, Sajid Mushtaq, Asif Loya and Mudassar Hussain did the pathological confirmation of cases at SKMCH \& RC, Lahore; Raqib Faraz, Aneel Yousaf, Hina Asif, Adna Atif and Ain ul Quader validated the data, checked for duplication and followed-up on the patients; and Muhammed Aasim Yusuf and Faisal Sultan set up the registry and directed it.

Contributors FB conceived the idea of the study, designed it, supervised the statistical analysis, did literature search, interpreted the results, drafted the manuscript and finalised it. SM did the case finding, indexing and coding of cases, computed the incidence rates and created figures and tables.

Competing interests None declared.

Ethics approval The Institutional Review Board of the Shaukat Khanum Memorial Cancer Hospital \& Research Center, Lahore, Pakistan.

Provenance and peer review Not commissioned; externally peer reviewed. Data sharing statement № additional data available.

Open Access This is an Open Access article distributed in accordance with the Creative Commons Attribution Non Commercial (CC BY-NC 4.0) license, which permits others to distribute, remix, adapt, build upon this work non-commercially, and license their derivative works on different terms, provided the original work is properly cited and the use is non-commercial. See: http://creativecommons.org/ licenses/by-nc/4.0/

(c) Article author(s) (or their employer(s) unless otherwise stated in the text of the article) 2017. All rights reserved. No commercial use is permitted unless otherwise expressly granted.

\section{REFERENCES}

1. World Bank Country and Lending Groups. The World Bank. Washington DC, USA, 2016. http://data.worldbank.org/about/ country-and-lending-groups\#Low_income (accessed 17 Feb 2017).

2. Population, Labor Force and Employment-Chapter 12. In: Pakistan Economic Survey 2015-2016. Islamabad, Pakistan: Ministry of Finance, Government of Pakistan, 2016:199-213. http://www. finance.gov.pk/survey/chapters_16/12_Population.pdf (accessed 9 Feb 2017).

3. Punjab Cancer Registry, SKMCH \& RC. Lahore, Pakistan, 2011. http://punjabcancerregistry.org.pk/ (accessed 17 Feb 2017).

4. Badar F, Mahmood S, Yusuf MA, et al. Epidemiology of cancers in Lahore, Pakistan, 2010-2012: a cross-sectional study. BMJ Open 2016;6:e011828. 
5. Holden $\mathrm{K}$, ed. ICD-10-CM Expert for Hospitals. The complete official code set. Codes valid October 1, 2015 through September 30, 2016. Salt Lake City, UT, USA: Optum360, LLC, 2015.

6. Surveillance, Epidemiology, and End Results Program. International Classification of Childhood Cancer. USA, 2016. https://seer.cancer. gov/iccc/iccc3.html (accessed 8 Feb 2017).

7. Steliarova-Foucher E, Stiller C, Lacour B, et al. International Classification of Childhood Cancer, third edition. Cancer 2005;103:1457-67.

8. International Association of Cancer Registries, European Network of Cancer Registries and International Agency for Research on Cancer, working group. Program for multiple primaries- IARC/IACR multiple primary rules. Appendix 3 . In: Ferlay J, Burkhard C, Whelan S, eds. Check and conversion programs for cancer registries (IARC/IACR tools for cancer registries). IARC Technical Report No. 42. Lyon: International Agency for Research on Cancer, 2005:38-45.

9. Census Publication No. 125. Population Census OrganizationStatistics Division, Government of Pakistan, Islamabad (2000). Statistical Tables-Part V'1998 District Census Report of Lahore'. Islamabad: Government of Pakistan, 2000:77-305

10. Boyle P, Parkin DM. Chapter 11-Statistical Methods for RegistriesIARC. In: Jensen OM, Parkin DM, MacLennan R, eds. Cancer Registration: Principles and Methods-IARC Scientific Publication No. 95. Lyon, France: International Agency for Research on Cancer, 1991. https://www.iarc.fr/en/publications/pdfs-online/epi/sp95/SP95. pdf (accessed 17 Feb 2017).

11. Cancer Incidence Statistics. Cancer Research UK. London, UK, 2017. http://www.cancerresearchuk.org/health-professional/cancerstatistics/incidence\#heading-Two (accessed 17 Feb 2017).

12. Overview of the UK Population. Office for National Statistics. London, UK: The National Archives, 2016. http:// webarchive.nationalarchives.gov.uk/20160105223359/http://www. ons.gov.uk/ons/rel/pop-estimate/population-estimates-for-ukengland-and-wales-scotland-and-northern-ireland/mid-2014/styoverview-of-the-uk-population.html (accessed 21 Aug 2017).

13. Hossain MS, Begum M, Mian MM, et al. Epidemiology of childhood and adolescent cancer in Bangladesh, 2001-2014. BMC Cancer 2016;16:104.

14. Arora RS, Eden TO, Kapoor G. Epidemiology of childhood cancer in India. Indian J Cancer 2009;46:264-73.

15. Badar F, Mahmood S. Cancer among children and adolescents at a cancer hospital in Pakistan. J Ayub Med Coll Abbottabad 2015;27:904-10.

16. Badar F, Mahmood S, Zaidi A, et al. Age-standardized incidence rates for childhood cancers at a cancer hospital in a developing country. Asian Pac J Cancer Prev 2009;10:753-8.

17. Curado MP, Edwards B, Shin HR, et al. Cancer Incidence in Five Continents Vol. IX, IARC-2007 IARC Scientific Publications No.160.
International Agency for Research on Cancer. Lyon, France, 2016. http://www.iarc.fr/en/publications/pdfs-online/epi/sp160/ (accessed 12 Aug 2016).

18. Steliarova-Foucher E, Colombet M, Ries LAG, eds. International Incidence of Childhood Cancer, Volume III (electronic version). International Agency for Research on Cancer, Lyon, France, 2017. http://iicc.iarc.fr/results/ (accessed 17 Feb 2017).

19. Cancer Statistics 2015. A presentation from the American cancer society, 2015. https://www.cancer.org/research/cancer-factsstatistics/all-cancer-facts-figures/cancer-facts-figures-2015.html (accessed 12 Aug 2016).

20. American Cancer Society. Cancer Statistics Center-Childhood and adolescent cancer incidence rates, 2008-2012. Data Source: North American Association of Central Cancer Registries (NAACCR). Atlanta, GA, USA: American Cancer Society, 2016. https:// cancerstatisticscenter.cancer.org/\#/data-analysis/ChildlncRate (accessed 18 Aug 2016).

21. Badar F, Mahmood S, Faraz R, et al. Epidemiology of breast cancer at the Shaukat Khanum Memorial Cancer Hospital and Research Center, Lahore, Pakistan.. J Coll Physicians Surg Pak 2015;25:738-42.

22. Shamsi U, Khan S, Usman S, et al. A multicenter matched case control study of breast cancer risk factors among women in Karachi, Pakistan. Asian Pac J Cancer Prev 2013;14:183-8.

23. Butt Z, Haider SF, Arif S, et al. Breast cancer risk factors: a comparison between pre-menopausal and post-menopausal women. J Pak Med Assoc 2012;62:120-4.

24. Gilani GM, Kamal S. Risk factors for breast cancer in Pakistani women aged less than 45 years. Ann Hum Biol 2004;31:398-407.

25. Pervez T, Anwar MS, Sheikh AM. Study of risk factors for carcinoma breast in adult female general population in Lahore. J Coll Physicians Surg Pak 2001;11:291-3.

26. Faheem $M$, Khurram M, Jafri IA, et al. Risk factors for breast cancer in patients treated at NORI Hospital, Islamabad. J Pak Med Assoc $2007 ; 57: 242$

27. NIH. Cancer Statistics; Interactive Tools-Fast Stats; by Cancer Site. Bethesda, MD, USA : National Cancer Center, 2017. https://seer. cancer.gov/ (accessed 25 Aug 2017).

28. WHO. Registry summary tables; Table: CI5X Cancer Incidence in Five Continents. Volume X-International Agency for Research on Cancer. Lyon, France: World Health Organization, 2013. http://ci5.iarc.fr/Default. aspx (accessed 29 Aug 2017).

29. Pakistan Bureau of Statistics. Population: Demographic Indicators-1998 Census and Area, Population, Density and Urban/ Rural Proportion. Population and Housing Indicators Population Census 1998. Islamabad, Pakistan: Pakistan Bureau of Statistics, Government of Pakistan. http://www.pbscensus.gov.pk/ (accessed 27 Sep 2017). 